\title{
PENGARUH RETURN ON INVESTMENT (ROI), EARNING PER SHARE (EPS), DAN DIVIDEN PER SHARE (DPS) TERHADAP HARGA SAHAM PERUSAHAAN PERTAMBANGAN YANG TERDAFTAR DI BURSA EFEK INDONESIA PERIODE 2012 - 2016
}

\author{
Lisdawati \\ H. Djayani Nurdin \\ H. Muh. Faisal \\ Program Studi S1 Manajemen Fakultas Ekonomi UniversitasTadulako \\ Email: lisdhaveronica27@gmail.com; djayani.nurdin@gmail.com
}

\begin{abstract}
The objective of this research is to find out the effect of Return on Invesment (ROI), Earning Per Share (EPS) and Dividend Per Share on the stock price of mining companies listed in the Indonesia Stock Exchange of 2012 - 2016 period, both partially and simultaneously. The sample used was 10 mining companies listed in the Indonesia Stock Exchange for 5 years, with the sampling technique used was purpose sampling. The data were analyzed through multiple linear regression analysis. The results of the research show that simultaneously Return on Investment (ROI), Earning Per Share (EPS) and Dividend Per Share have a significant effect on stock price. Partially the variables of Return on Investment (ROI), Earning Per Share (EPS) and Dividend Per Share have a significant effect on stock prices.
\end{abstract}

Keywords: Return On Invesment (ROI), Earning Per Share (EPS), Dividend Per Share (DPS), and Share Price

Abstrak

Penelitian ini bertujuan untuk mengetahui pengaruh Return On Investment (ROI), Earning Per Share (EPS), Dividen Per Share (DPS) terhadap Harga Saham pada perusahaan pertambangan yang terdaftar di Bursa Efek Indonesia periode 2012-2016, baik secara parsial maupun secara serempak. Sampel yang digunakan penelitian ini yaitu sebanyak 10 perusahaan pertambangan yang terdaftar di Bursa Efek Indonesia selama 5 tahun, dengan teknik penarikan sampel yang digunakan adalah purposive sampling. Metode analisis data yang digunakan dalam penelitian ini adalah Regresi Linear Berganda. Hasil penelitian menunjukan bahwa secara serempak Return On Investment (ROI), Earning Per Share (EPS), Dividen Per Share (DPS) berpengaruh signifikan terhadap terhadap Harga Saham. Secara parsial variabel Return On Investment (ROI), Earning Per Share (EPS), Dividen Per Share $(D P S)$ berpengaruh signifikan terhadap Harga Saham.

Kata kunci: Return On Investment (ROI), Earning Per Share (EPS), Dividen Per Share (DPS), dan Harga Saham

\section{PENDAHULUAN}

\section{Latar Belakang}

Divisi prospektif adalah industri pertambangan bagi Indonesia untuk meningkatkan penghasialn penjualan prodak ke luar negeri, infrastruktur, pengembangan kegiatan ekonomi, lowongan pekerjaan yang dibuka dan pendapatan daerah. Negara Indonesia yang melimpah dengan sumber daya alam seperti industri pertambangan memiliki peluang usaha yang sangat menguntungkan. Sektor pertambangan menarik banyak investor untuk menginvestasikan kekayaan mereka. Salah satu 
industri strategis bagi Indonesia adalah sektor pertambangan untuk pembangunan ekonomi nasional. Berikut ini perkembangan produksi tambang di Indonesia tahun 2012-2016.

Tabel 1.1

Produksi Barang Tambang Mineral/Minyak Bumi/Gas Bumi Per Ton

Tahun 2012-2016

\begin{tabular}{|c|c|c|c|c|c|c|}
\hline \multirow[b]{2}{*}{ No } & \multirow[b]{2}{*}{ Jenis Tambang } & \multicolumn{5}{|c|}{ Tahun } \\
\hline & & $\begin{array}{l}2012 \\
\text { (Ton) }\end{array}$ & $\begin{array}{l}2013 \\
\text { (Ton) }\end{array}$ & $\begin{array}{l}2014 \\
\text { (Ton) }\end{array}$ & $\begin{array}{l}2015 \\
\text { (Ton) }\end{array}$ & $\begin{array}{l}2016 \\
\text { (Ton) }\end{array}$ \\
\hline \multicolumn{7}{|c|}{ Mineral Logam } \\
\hline 1 & Batu Bara & 415.765 .068 & 466.307 .241 & 458.462 .513 & 435.742 .874 & 405.871 .432 \\
\hline 2 & Bauksit & 1.152 .322 & 935.211 & 2200.000 & 24.714 .940 & 2.539 .274 \\
\hline 3 & Nikel & 41.193 .335 & 47.106 .534 & 65.047 .388 & 39.034 .912 & 34.063 .566 \\
\hline 4 & Emas & 68.220 & 69.291 & 59.804 & 69.349 & 92.339 \\
\hline 5 & Perak & 268.967 & 226.051 & 359.451 & 335.04 & 227.173 \\
\hline 6 & Granit & 4.514 .654 & 1.793 .440 & 2.050 .000 & 2.172 .080 & 3.316 .813 \\
\hline 7 & Pasir Besi & 1.814 .544 & 11.545 .752 & 22.353 .337 & 5.951 .400 & 3.838 .546 \\
\hline \multicolumn{7}{|c|}{ Mineral Non Logam } \\
\hline 1. & Marmer & 865.409 & 678.610 & 754.696 & 707.163 & 529.368 \\
\hline 2. & Pasir & 252.746 .435 & 309.448 .774 & 261.691 .048 & 302.439 .255 & 373.022 .443 \\
\hline 3. & Batu & 83.668 .562 & 89.590 .918 & 84.113 .959 & 104.274 .218 & 54.413 .501 \\
\hline \multicolumn{7}{|c|}{ Minyak Bumi } \\
\hline 1. & Premium & 64.460 & 67684 & 67819 & 70828 & 71733 \\
\hline 2. & Solar & 119.568 & 122.099 & 122.907 & 129.503 & 129.306 \\
\hline 3. & Minyak Tanah & 14.378 & 10.808 & 9.614 & 7.332 & 4.977 \\
\hline 4. & Avtur & 579 & 1.352 & 783 & 2.903 & 3.230 \\
\hline 5. & Avgas & 17.061 & 19.050 & 18.264 & 19.938 & 20.240 \\
\hline \multicolumn{7}{|c|}{ Gas Bumi } \\
\hline 1. & $\mathrm{LPG}$ & 9.143 .476 & 7.287 .443 & 6.635 .234 & 6.361 .221 & 8.084 .025 \\
\hline 2. & $\mathrm{CN} \mathrm{G}$ & 306.456 & 298.809 & 269.623 & 252.927 & 276.387 \\
\hline 3. & L N G & 13.280 .421 & 9.537 .878 & 12.764 .234 & 22.379 .112 & 21.450 .431 \\
\hline
\end{tabular}

Sumber: bps.go.id 2018

Berdasarkan Tabel 1.1 diatas, menunjukan bahwa produksi tambang mengalami fluktuasi. Produksi tambang mineral logam didominasi oleh batu bara dari tahun 2012-2015, sedangkan yang terendah diperoleh konsentrat tin selama tahun 2012-2016, dan mineral non logam didominasi oleh pasir sedangkan yang terendah di peroleh batu. Produksi tambang kategori minyak bumi didominasi oleh solar dari tahun 2012-2016, dan yang terendah diperoleh avtur dari tahun 2012-2016. Sedangkan pada gas bumi didominasi oleh (LNG) dari tahun 2012-2016 dan yang terendah terdapat pada (CNG). Tetapi produksi tambang yang menjadi sorotan di Sulawesi Tengah yaitu nikel menjadi salah satu tambang yang disukai perusahaan asing, di Sulawesi Tengah tepatnya di kabupaten Morowali terdapat banyak perusahaan nikel yang rata - rata karyawannya terdiri dari tenaga kerja asing. Sejak hadirnya perusahaan ini sangat berdampak positif bagi masyarakat setempat dengan bertumbuhnya perekonomian masyarakat dan menarik tenaga kerja anak lokal. Investasi saham di pasar modal menjadi pertimbangan bagi investor. Penyebab ketidakpastian investor dalam menentukan keputusan 


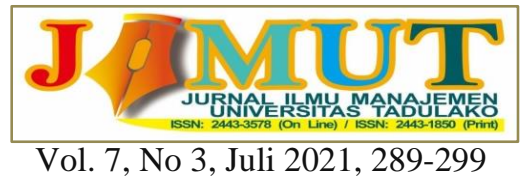

investasinya adalah fluktuasi harga saham yang tidak menentu. Menurut Abid (2006:51) kinerja suatu perusahaan terlihat dari tinggi rendahnya nilai saham. Untuk mempertimbangkan keputusan dalam berinvestasi diperlukan data dan informasi. Dapat diketahui bahwa terjadi perbedaan jumlah laba terhadap Perusahaan Pertambangan yang terdaftar di Bursa Efek Indonesia dari tahun 2012-2016 dan mengalami fluktuasi setiap tahunnya. Jumlah laba tertinggi dicapai oleh PT. Bumi Resources, Tbk (BUMI) sebesar Rp. 3.547.424 pada tahun 2013 dengan harga saham sebesar Rp. 380. Sedangkan jumlah laba terendah terdapat pada PT. Atlas Resources, Tbk (ARII) yaitu Rp. 11.641 dengan harga saham sebesar Rp.520.

Fenomena menunjukan EPS dan harga saham mengalami fluktuasi. Pada tahun 2012, dengan nilai tertinggi EPS diperoleh PT. Indo Tambang Raya Megah, Tbk (ITMG) sebesar 785.85 dan memiliki harga saham tertinggi sebesar 41.550, sedangkan nilai EPS terendah diperoleh PT. Bumi Resources, Tbk (BUMI) sebesar -289.55 dan harga saham terendah terdapat pada PT. Ratu Prabu Energi, Tbk (ARTI) sebesar 260. Selanjutnya, pada tahun 2013 nilai EPS tertinggi diperoleh PT. Indo Tambang Raya Megah, Tbk (ITMG) sebesar 942.68 dan memilki harga saham tertinggi sebesar 28.500, sedangkan nilai EPS terendah terdapat pada PT. Bumi Resources, Tbk (BUMI) sebesar 359.72 dan memiliki harga saham terendah 380. Pada tahun 2014 nilai EPS tertinggi diproleh PT. Indo Tambang Raya Megah, Tbk (ITMG) sebesar diperoleh 2,203.61 dan memiliki harga saham sebesar 15.375, sedangkan nilai EPS terendah terdapat pada PT. Bayan Resources, Tbk (BYAN) sebesar 516.26, dan harga saham terendah terdapat pada PT. Bumi Resources, Tbk (BUMI) sebesar 80. Pada tahun 2015 nilai EPS tertinggi diperoleh PT. Indo Tambangraya Megah, Tbk (ITMG) sebesar 818.60 dan memilki harga saham tertinggi sebesar 5.725. sedangkan nilai EPS terendah terdapat pada PT. Medco Energy Internasional, Tbk (MEDC) sebesar -800.03 dan harga saham terendah terdapat pada PT. Bumi Resources, Tbk (BUMI) sebesar 50. Tahun 2016, nilai EPS tertinggi diperoleh PT. Indo Tambangraya Megah, Tbk (ITMG) sebesar 1,554.27 dan memilki harga saham tertinggi sebesar 16.875, sedangkan nilai EPS terendah terdapat pada PT. Petrosea, Tbk (PTRO) sebesar -105.69 dan harga saham terendah terdapat pada PT. Ratu Prabu Energi, Tbk (ART) sebesar 50.

Fenomena menunjukan DPS dan harga saham mengalami fluktuasi. Nilai DPS tertinggi diperoleh PT. Indo Tambang Raya Megah, Tbk (ITMG) sebesar 790.3 dan memiliki harga saham tertinggi sebesar 41.550 pada tahun 2012, sedangkan nilai DPS terendah diperoleh PT. Aneka Tambang, Tbk (ANTM) sebesar 3.63 dan harga saham sebesar 895. Menurut signalling theory menyatakan informasi yang diumumkan oleh emiten berkaitan dengan informasi perusahaan dan nantinya dapat menjadi sinyal positif maupun negatif akan mempengaruhi harga saham dari emiten tersebut. DPS merupakan hal yang dipertimbangkan oleh investor dalam berinvestasi.

Lokasi penelitian yang peneliti lakukan adalah di Bursa Efek Indonesia melalui Website (www.idx.co.id) ialah karena peneliti ingin mengetahui seberapa besar pengaruh Return On Investment (ROI), Earning Per Share (EPS), dan Dividen Per Share (DPS) terhadap Harga Saham Perusahaan Pertambangan dengan tahun pengamatan 2012 sampai 2016.

\section{KAJIAN LITERATURE}

\section{Pengertian Harga Saham}

Sartono (2008:70) menyatakan bahwa Harga Saham terbentuk melalui sistem permintaan dan penawaran dipasar modal. Apabila suatu saham penawarannya bertambah maka harga saham condong turun. Sebaliknya apabila bertambahnya permintaan, maka harga saham condong naik. Artinya para pemegang saham sebagai yang mengajukan permintaan sedangkan pihak emiten menawarkan harga saham. 


\section{Nilai Saham}

Ada tiga jenis penilaian saham (Hartono, 2000:79), yaitu:

1. Nilai Buku ialah nilai aset yang tersisa setelah dikurangi kewajiban perusahaan jika dibagikan.

2. Nilai Pasar merupakan harga yang dibentuk oleh permintaan dan penawaran saham di pasar modal atau disebut juga dengan harga pasar sekunder.

3. Nilai Intrinsik adalah nilai saham yang menentukan harga wajar suatu saham agar saham tersebut mencerminkan nilai saham yang sebenarnya sehingga tidak terlalu mahal.

\section{Yang Mempengaruhi Harga Saham}

Faktor - faktor yang mempengaruhi fluktuasi harga saham dapat berasal dari internal dan eksternal. Harga saham yang terjadi pada bursa efek selalu berfluktuasi dari waktu ke waktu. Fluktuasi harga saham akan ditentukan oleh kekuatan penawaran dan permintaan.

\section{Return on Investment (ROI)}

Return On Invesment (ROI) merupakan pengukuran kemampuan perusahaan secara keseluruhan didalam menghasilkan keuntungan dengan jumlah keseluruhan aktiva terhadap perusahaan. Menurut Sofyan Syafri Harahap (2007:305) ROI merupakan rasio yang dapat menunjukan persenan laba bersih yang diperoleh bila diukur dari modal pemilik.

\section{Earning Per Share (EPS)}

Menurut Darmadji dan Fakhruddin (2000:139) bahwa yang di maksud dengan Earning Per Share (EPS) adalah rasio yang menunjukan seberapa besar keuntungan (return) yang diperoleh investor atau pemegang saham per saham.

\section{Dividen Per Share (DPS)}

Kemampuan perusahaan dalam meningkatkan kemakmuran bagi perusahaan dan pemegang saham akan mempunyai pengaruh positif terhadap nilai perusahaan. Berdasarkan hasil penelitian yang dilakukan oleh E.F. Fama dan Einde Evana (2008:101) menyimpulkan bahwa rata-rata harga saham meningkat setelah pembagian dividen.

\section{Kerangka Pemikiran}

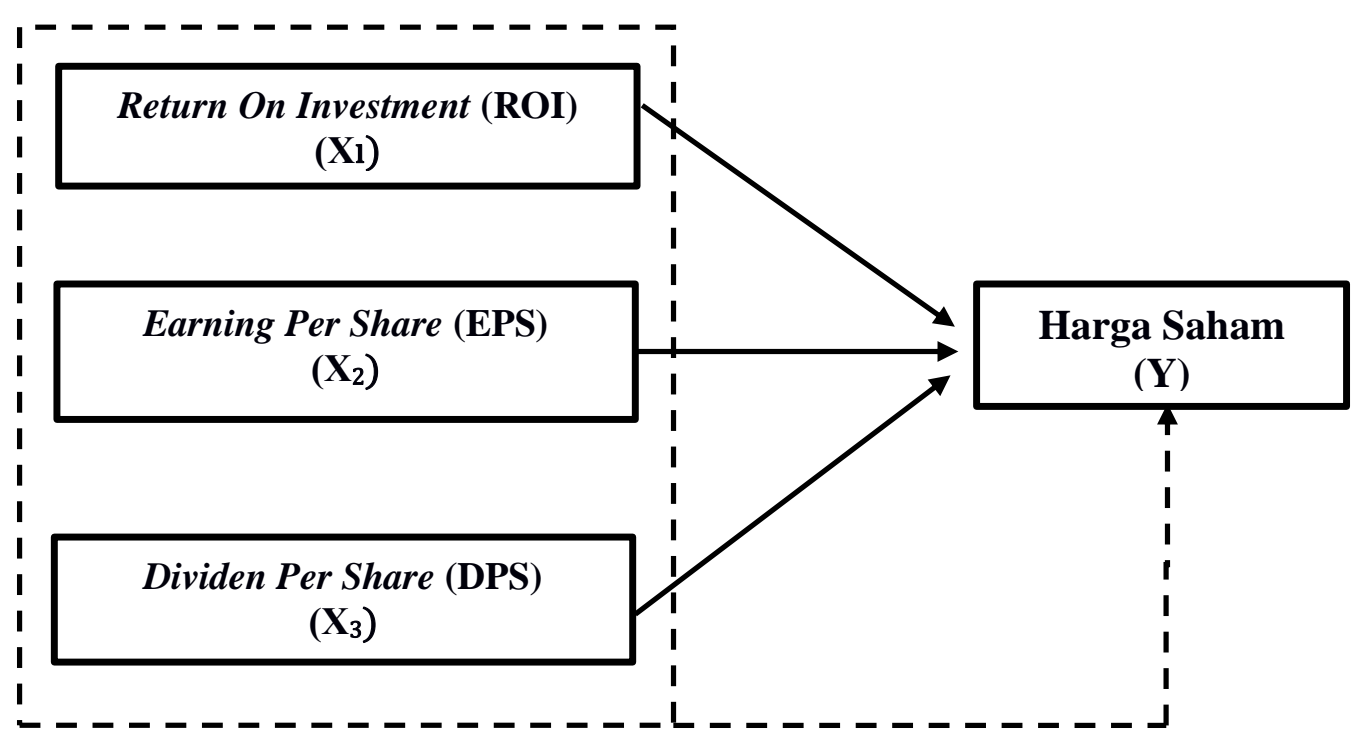

Gambar 2.1

Kerangka Pemikiran 


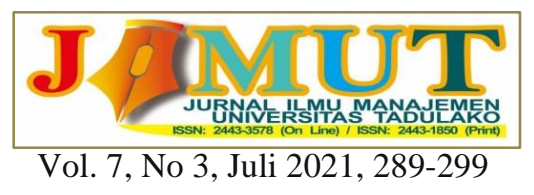

Keterangan :

$\longrightarrow$ : Parsial

$----\rightarrow$ : Serempak

\section{METODE PENELITIAN}

\section{Jenis Penelitian}

Jenis penelitian yang dilakukan adalah kausal, yaitu hubungan yang bersifat sebab akibat (Sugiyono, 2014:56). Dasar pemilihan jenis penelitian ini untuk mengetahui hubungan variabel yaitu tiga variabel terhadap satu variabel lainnya. Dalam hal ini seberapa besar Pengaruh Return On Investment (ROI), Earning Per Share (EPS) dan Dividen Per Share (DPS) Terhadap Harga Saham pada Perusahaan Pertambangan Yang Terdaftar di Bursa Efek Indonesia.

\section{Lokasi Penelitian}

Lokasi penelitian yang peneliti lakukan adalah di Bursa Efek Indonesia melalui Website (www.idx.co.id) peneliti mengambil objek perusahaan pertambangan dengan tahun pengamatan 2012 sampai 2016.

\section{Jenis dan Sumber Data}

Untuk memperoleh data yang diperlukan, maka dilakukan penelitian dengan jenis data kualitatif adalah penelitian yang berlandaskan pada filsafat postpositivisme, dan data kuantitatif adalah penelitian yang berlandaskan pada filsafat positivisme. Dan sumber data yaitu data yang diperoleh secara tidak langsung. Data sekunder yang diperoleh dalam penelitian ini yaitu laporan keuangan tahunan perusahaan pertambangan yang bersumber dari website Bursa Efek Indonesia (www.idx.co.id) yang diterbitkan oleh masing-masing perusahaan sampel.

\section{Populasi dan Sampel}

Populasi digunakan dalam penelitian ini sebanyak 38 perusahaan. Teknik pengambilan sampel dalam penelitian ini menggunakan teknik purposive sampling. Berdasarkan kriteria diperoleh jumlah sampel adalah sebanyak 10 perusahaan pertambangan.

\section{Teknik Pengmpulan Data}

Teknik mengumpulkan data yang digunakan dalam penelitian ini adalah dokumentasi dokumentasi berupa laporan keuangan. Data tersebut diambil/diakses melalui www.idx.co.id.

\section{Teknik Analisis Data}

\section{Uji Asumsi Klik}

Uji asumsi klasik yang digunakan untuk memastikan bahwa data berdistribusi normal, tidak terdapat multikolinearitas dan heteroskedastisitas dalam model yang digunakan.

\section{Uji Hipotesis Secara Serempak (Uji F)}

Uji F (Serempak) menunjukan variabel independen berpengaruh secara bersama-sama terhadap variabel dependen. Dasar pengambilan keputusan adalah hipotesis akan diterima apabila nilai probabilitas tingkat kesalahan $\mathrm{F}$ atau $\mathrm{p}$ value lebih kecil dari taraf signifikansi tertentu (taraf signifikansi 0,05).

1. F hitung $>\mathrm{F}$ tabel, maka Ho ditolak dan Ha diterima (Signifikan)

2. F hitung $<$ F tabel, maka Ho diterima dan Ha ditolak (Tidak Signifikan)

\section{Uji Hipotesis Secara Parsial (Uji T)}

Uji t ( Parsial) Uji parsial digunakan untuk mengetahui apakah masing-masing variabel Return on Investment (ROI), Earning per Share (EPS), dan Dividen per Share (DPS) mempunyai pengaruh terhadap harga saham yang dianggap konstan. Jika nilai probabilitas tingkat kesalahan $t$ atau $\mathrm{p}$ value lebih kecil dari taraf signifikansi $(0,05)$ yang diterima oleh hipotesis sebagai keputusan yang diambil. 
1. t-hitung $>\mathrm{t}$-tabel, maka Ho ditolak dan Ha diterima (Signifikan)

2. t-hitung < t-tabel, maka Ho diterima dan Ha ditolak ( Tidak Signifikan)

\section{Analisis Regresi Linear Berganda}

Penelitian ini menggunakan teknik regresi linear berganda (Multiple Regression Model) guna memahami hubungan variabel independen dan dependen. Digunakan analisis regresi linear berganda karena melibatkan lebih dari dua variabel independen. Model umum analisis regresi tersebut adalah sebagai berikut, Sugiyono, (2013:211):

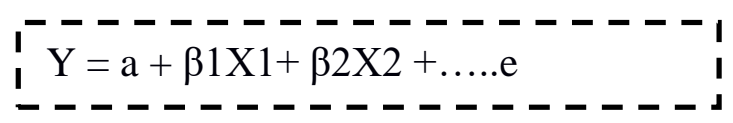

$$
\begin{array}{ll}
\text { Dimana : } \\
\mathrm{Y} & =\text { Variabel dependen } \\
\mathrm{a} & =\text { Konstanta } \\
\mathrm{b}_{1}-\mathrm{b}_{\mathrm{n}} & =\text { Koefisien regresi } \\
\mathrm{X}_{1}-\mathrm{X}_{\mathrm{n}} & =\text { Variabel independen } \\
\mathrm{e} & =\text { standard error }
\end{array}
$$

\section{HASIL DAN PEMBAHASAN}

\section{Hasil Statistik Deskriptif}

Berdasarkan hasil analisis deskriptif statistik, maka berikut didalam Tabel 4.5 akan ditampilkan karakteristik sampel yang digunakan didalam penelitian ini meliputi: jumlah sampel $(\mathrm{N})$, rata-rata sampel (mean), nilai maksimum, nilai minimum, serta standar deviasi, untuk masing-masing variabel ROI, EPS, DPS, dan Harga Saham sebagai berikut :

Tabel 4.5

Hasil Statistik Deskriptif

\begin{tabular}{|l|r|r|r|r|r|}
\hline \multicolumn{7}{|c|}{ Descriptive Statistics } \\
\hline ROI & N & Minimum & Maximum & Mean & Std. Deviation \\
EPS & 50 & .10 & 264.95 & 21.6368 & 44.70415 \\
DPS & 50 & 1.30 & 5728.40 & 873.5518 & 1415.26977 \\
Harga Saham & 50 & .41 & 3974.80 & 482.1436 & 818.56608 \\
Valid N (listwise) & 50 & 173.00 & 41550.00 & 3103.4600 & 7407.30748 \\
\hline
\end{tabular}

Sumber: Lampiran 2

Berdasarkan Tabel 4.5 diatas, dapat dijelaskan bahwa statistik deskriptif diatas ROI pada 50 sampel perusahaan pertambangan memiliki mean sebesar $21.6 \%$ ROI minimum sebesar $0.1 \%$ yang terdapat pada perusahaan PT. Vale Indonesia, Tbk (INCO), sedangkan ROI maximum sebesar 264.9\%, terdapat perusahaan pada PT. Samindo Resources, Tbk (MYOH) dan standar deviasi sebesar 44.07415 .

Earning Per Share dari 50 sampel perusahaan pertambangan memiliki mean sebesar 873.5\%, nilai minimum sebesar Rp. 1.3 terdapat pada perusahaan PT. Timah, Tbk (TINS). Nilai maximum sebesar Rp. 5728.4 terdapat pada perusahaan PT. Elnusa, Tbk (ELSA) dan standar deviasi sebesar $1415.26 \%$. 


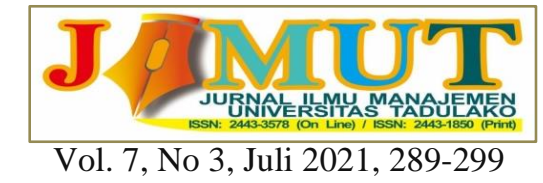

Dividen Per Share dari 50 sampel perusahaan pertambangan memiliki mean sebesar $482.14 \%$, nilai minimum sebesar $0.41 \%$ terdapat pada perusahaan PT. Timah, Tbk (TINS). Nilai maximum sebesar 3974.8\% terdapat pada perusahaan PT. Elnusa, Tbk (ELSA) dan standar deviasi sebesar $818.56 \%$.

Harga saham dari 50 sampel perusahaan pertambangan memiliki mean sebesar 1195.7\%, nilai minimum sebesar Rp. 173 terdapat pada perusahaan PT. Elnusa, Tbk (ELSA). Nilai maximum sebesar Rp. 41.550 terdapat pada perusahaan PT. Indo Tambangraya Megah, Tbk (ITMG) dan standar deviasi sebesar $7407.30 \%$.

\section{Tabel 4.8}

\section{Hasil Uji Serempak (Uji F-Statistik dan $\mathbf{R}^{2}$ )}

\begin{tabular}{|c|c|c|c|c|}
\hline $\mathbf{N}$ & F-hitung & Sig. & $\mathbf{R}^{2}$ & Kesimpulan \\
\hline 50 & 4.202 & 0,010 & 0.215 & Signifikan \\
\hline
\end{tabular}

Pada Tabel 4.8 diatas menunjukan nilai Sig. sebesar 0,010 dengan probabilitas tingkat kesalahan lebih kecil dari tingkat signifikansi yang diharapkan $(0,010<0,05)$, maka hipotesis kelima (H1) "ROI, EPS, dan DPS berpengaruh secara serempak terhadap harga saham pada perusahaan pertambangan yang terdaftar di Bursa Efek Indonesia periode 2012-2016". Berdasarkan pada Tabel 4.8 di atas, diketahui nilai $\mathrm{R}^{2}$ sebesar 0,215 hal ini berarti keempat variabel independen (ROI, EPS dan DPS) mampu menjelaskan perubahan terhadap variabel dependen (harga saham) sebesar 21,5\% sedangkan sisanya 78.5\% dijelaskan oleh variabel lain yang tidak diajukan dalam penelitian ini. Sedangkan tingkat keeratan hubungan antara ketiga variabel bebas terhadap harga saham, dapat dilihat melalui nilai Multiple R 0.464 atau sebesar 46,4\%.

Tabel 4.9

Hasil Uji Parsial

\begin{tabular}{|c|c|c|c|c|}
\hline Variabel & $\begin{array}{c}\text { Koefisien Regresi } \\
(\mathbf{B})\end{array}$ & t hitung & Sig. & Kesimpulan \\
\hline Ln_ROI & 0.225 & 1.615 & 0.013 & Signifikan \\
\hline Ln_EPS & 0.538 & 3.440 & 0.001 & Signifikan \\
\hline Ln_DPS & 0.390 & 2.654 & 0.011 & Signifikan \\
\hline
\end{tabular}

Sumber: Lampiran 3

Berdasarkan Tabel 4.9 di atas, hasil uji parsial diatas dapat dijelaskan sebagai berikut:

1. Pengujian pengaruh Return On Investment (ROI) terhadap harga saham menghasilkan koefisien regresi sebesar 0,225 , diperoleh juga thitung sebesar 1,615 dengan probabilitas tingkat kesalahan sebesar 0,013 lebih kecil dari taraf signifikansi kurang dari 0,05, maka hipotesis pertama (H1) ROI berpengaruh signifikan terhadap harga saham pada perusahaan pertambangan yang terdaftar di Bursa Efek Indonesia. Hasil analisis menunjukan adanya pengaruh positif dan signifikan Return On Investment (ROI) terhadap harga saham.

2. Pengujian pengaruh Earning Per Share (EPS) terhadap harga saham menghasilkan koefisien regresi sebesar 0.538 , diperoleh juga $t_{\text {hitung }}$ sebesar 3.440 dengan probabilitas tingkat kesalahan sebesar 0,001 lebih kecil dari taraf signifikansi kurang dari 0,05, maka hipotesis pertama (H2) EPS berpengaruh signifikan terhadap harga saham pada perusahaan pertambangan yang terdaftar di Bursa Efek Indonesia. Hasil analisis menunjukan adanya pengaruh positif dan signifikan Earning Per Share (EPS) terhadap harga saham. 
3. Pengujian pengaruh Dividen Per Share (DPS) terhadap harga saham menghasilkan koefisien regresi sebesar 0,390, diperoleh juga $t_{\text {hitung }}$ sebesar 2,654 dengan probabilitas tingkat kesalahan sebesar 0,011 lebih kecil dari taraf signifikansi kurang dari 0,05, maka hipotesis pertama (H1) DPS berpengaruh signifikan terhadap harga saham pada perusahaan pertambangan yang terdaftar di Bursa Efek Indonesia. Hasil analisis menunjukan adanya pengaruh positif dan Dividen Per Share (DPS) terhadap harga saham.

Tabel 4.10

Rekapitulasi Analisis Regresi Linear Berganda (Log-Linear)

\begin{tabular}{|c|c|c|c|c|}
\hline \multicolumn{5}{|c|}{ Dependen Variabel Y = Harga Saham } \\
\hline \multirow[t]{2}{*}{ Variabel Independen } & \multicolumn{2}{|c|}{ Unstandardized Coefficients } & \multirow{2}{*}{$\mathbf{t}$} & \multirow{2}{*}{ Sig t. } \\
\hline & B & Standar Error & & \\
\hline $\mathrm{C}=$ Costanta & 7.490 & 0.467 & 16.022 & 0.000 \\
\hline $\mathrm{X}_{1}$ Ln_Return On Investment (ROI) & 0.225 & 0.140 & 1.615 & 0.013 \\
\hline $\mathrm{X}_{2}$ Ln_Earning Per Share (EPS) & 0.538 & 0.156 & 3.440 & 0.001 \\
\hline $\mathrm{X}_{3} \mathrm{Ln}_{-}$Dividen Per Share (DPS) & 0.390 & 0.147 & 2.654 & 0.011 \\
\hline $\begin{array}{l}\text { Multiple } R=0.464 \text { Sig. } F=0.010 \\
R \text { Square }\left(R^{2}\right)=0.215\end{array}$ & & & & \\
\hline
\end{tabular}

Sumber: Lampiran 3

Hasil analisis regresi linear berganda tersebut dapat dimasukan ke dalam persamaan menjadi sebagai berikut:

\section{Ln_Harga Saham $=7,490+0,225$ Ln_ROI + 0,538 Ln_EPS + 0,390 Ln_DPS}

Bentuk persamaan regresi diatas dapat diartikan sebagai berikut:

1. Konstanta $=7,490$, berarti bahwa apabila tidak ada variabel rasio keuangan ROI, EPS, dan DPS maka besarnya harga saham perusahaan pertambangan adalah Rp.7,490.

2. $b_{1}=0,225$. Koefisien regresi ROI sebesar 0,225 menunjukan bahwa ROI mempunyai arah koefisien regresi positif yang berarti setiap kenaikan ROI sebesar $1 \%$ akan menaikan harga saham sebesar $0,225 \%$.

3. $b_{2}=0,538$. Koefisien regresi EPS sebesar 0,538 menunjukan bahwa EPS mempunyai arah koefisien regresi postif yang berarti setiap kenaikan EPS sebesar 1\% akan menaikan harga saham sebesar $0,538 \%$.

4. $b_{3}=0,390$. Koefisien regresi DPS sebesar 0,390 menunjukan bahwa DPS mempunyai arah koefisien regresi positif yang berarti setiap kenaikan DPS sebesar 1\% akan menaikan harga saham sebesar $0,390 \%$.

\section{Pembahasan}

Pengaruh Return On Investment (ROI), Earning Per Share (EPS), dan Dividen Per Share (DPS) terhadap Harga Saham

Hasil analisis regresi ganda menunjukan nilai koefisien determinasi $\left(\mathrm{R}^{2}\right)$ yang berarti bahwa perubahan yang terjadi pada harga saham dapat dijelaskan oleh variabel Return On Investment (ROI), Earning Per Share (EPS), dan Dividen Per Share (DPS) sebesar 21,5\%, sedangkan sisanya 78,5\% dijelaskan oleh variabel lain yang tidak diajukan dalam penelitian ini. 


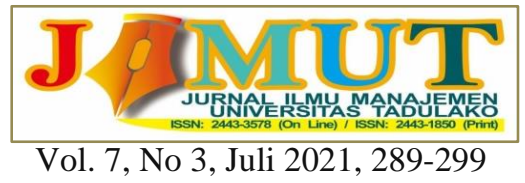

\section{Pengaruh Return On Investment Terhadap Harga Saham}

Hasil penelitian ini menunjukan bahwa pengaruh Return On Investment (ROI) terhadap harga saham menghasilkan koefisien regresi sebesar 0,225, diperoleh juga $t_{\text {hitung }}$ sebesar 1,615 dengan probabilitas tingkat kesalahan sebesar 0,013 lebih kecil dari taraf signifikansi kurang dari 0,05. Hasil analisis menunjukan adanya pengaruh positif dan signifikan Return On Investment (ROI) terhadap harga saham.

\section{Pengaruh Earning Per Share (EPS) Terhadap Harga Saham}

Hasil penelitian ini menunjukan bahwa pengaruh Earning Per Share (EPS) terhadap harga saham menghasilkan koefisien regresi sebesar 0.538, diperoleh juga thitung sebesar 3.440 dengan probabilitas tingkat kesalahan sebesar 0,001 lebih kecil dari taraf signifikansi kurang dari 0,05. Hasil analisis menunjukan pengaruh yang signifikan earning per share (EPS) terhadap harga saham.

\section{Pengaruh Dividen Per Share (DPS) Terhadap Harga Saham}

Hasil penelitian ini menunjukan pengaruh Dividen Per Share (DPS) terhadap harga saham menghasilkan koefisien regresi sebesar 0,390, diperoleh juga $t_{\text {hitung }}$ sebesar 2,654 dengan probabilitas tingkat kesalahan sebesar 0,011 lebih kecil dari taraf signifikansi kurang dari 0,05, Hasil analisis menunjukan adanya pengaruh positif dan dividen per shasre (DPS) terhadap harga saham.

\section{KESIMPULAN DAN SARAN}

\section{Kesimpulan}

Berdasarkan hasil analisis dan pembahasan yang telah dilakukan pada penelitian ini maka dapat ditarik beberapa kesimpulan, sebagai berikut:

1. Return On Investment (ROI), Earning Per Share (EPS), dan Dividen Per Share (DPS) secara serempak berpengaruh signifikan terhadap harga saham pada perusahaan pertambangan yang terdaftar di Bursa Efek Indonesia.

2. Return On Investment (ROI) secara parsial berpengaruh signifikan terhadap harga saham pada perusahan pertambangan yang terdaftar di Bursa Efek Indonesia.

3. Earning Per Share (EPS) secara parsial berpengaruh signifikan terhadap harga saham pada perusahan pertambangan yang terdaftar di Bursa Efek Indonesia.

4. Dividen Per Share (DPS) secara parsial berpengaruh signifikan terhadap harga saham pada perusahan pertambangan yang terdaftar di Bursa Efek Indonesia.

\section{Saran}

Berdasarkan hasil analisis dan pembahasan, maka saran yang dapat diberikan adalah sebagai berikut:

1. Bagi investor dalam mengambil keputusan investasi saham pada perusahaan pertambangan hendaknya mempertimbangkan rasio ROI, EPS, dan DPS karena secara serempak berpengaruh terhadap harga saham. Hal ini diperkuat dengan hasil penelitian yang menyebutkan Return On Investment (ROI), Earning Per Share (EPS), dan Dividen Per Share (DPS) berpengaruh signifikan terhadap harga saham.

2. Bagi Perusahaan, supaya tingkat risiko perusahaan secara keseluruhan juga menjadi perhatian selain memperhatikan pencapaian laba. Menjadi perusahaan pilihan keputusan investasi investor, dibutuhkan pertimbangan matang dalam mengelola keuangan perusahaan, agar tidak mengorbankan keberlangsungan perusahaan jangka panjang demi mendapatkan laba jangka pendek.

3. Bagi Peneliti, agar membandingkan teori yang telah diperoleh selama kuliah dengan keadaan yang sebenarnya. 


\section{REFERENSI}

Abid Djazuli. 2006. "Pengaruh EPS, ROI, dan ROE Terhadap Perubahan Harga Saham Pada Perusahaan Sektor Manufaktur Pada Bursa Efek Jakarta (BEJ)”. Fordema.Volume 6.Nomor: 5162.

Agus, Sartono. 2008. Manajemen Keuangan Teori dan Aplikasi. Edisi Empat. Yogyakarta: BPFE

Agus, R. Sartono. 2010. Manajemen Keuangan Teoridan Aplikasi. Edisi. Keempat. Yogyakarta: BPFE.

Brigham, Eugene dan Joel F Houston, 2006. Dasar - Dasar Manajemen Keuangan. Edisi 10 Buku 1. Jakarta: Salemba Empat.

Darmadji, Tjiptono dan Hendy M. Fakhruddin, 2006. Pasar Modal di Indonesia. Jakarta: PT Salemba Empat.

Denies Priatinah Prabandaru Adhe Kusuma (Jurnal Nominal / Volume I Nomor I / Tahun 2012), "Pengaruh Return On Investment (ROI), Earning Per Share (EPS), dan Dividen Per Share (DPS) Terhadap Harga Saham Perusahaan Pertambangan yang Terdaftar Di BEI Periode 2008 2010".

Endah Novianti (2011) Pengaruh ROE, ROI, EPS dan PER terhadap Harga Saham (Studi pada perusahaan industry food and beverages yang listing di BEI periode penelitian tahun 20062009).

Ghozali, Imam. (2011). Aplikas iAnalisis Multivariate dengan Program IBM SPSS 19. Semarang: Badan Penerbit Universitas Diponegoro.

Harahap, Sofyan Syafri. 2002. Analisa Kritis Atas Laporan Keuangan. Jakarta: Grafindo Persada

Hartono, Jogiyanto. 2000. “Teori Portofolio Dan Analisis Investasi”. BPFE,. Yogyakarta.

Imanzah Yoga Ramadhan, "Pengaruh Return On Investment (ROI), Earning Per Share (EPS) dan Price Earning Ratio (PER) Terhadap Harga Saham (Studi pada Perusahaan Telekomunikasi yang listing di BEI tahun 2009 - 2012)”.

Indriyo Gitosudarmo dan Basri. 2002. Manajemen Keuangan. Yogyakarta: BPFE.

Irawati, Susan. 2006. Manajemen Keuangan. Cetakan Kesatu. Bandung: PT.Pustaka

Jogiyanto, H. 2008. Teori Portofolio dan Analisis Investasi. Yogyakarta: BPFE

Kasmir. 2015. Analisis Laporan Keuangan. Jakarta : PT Raja Grafindo Persada.

Machfoedz, Mas'ud. 2000. Akuntansi Manajemen. Buku 1. BPFE: Yogyakarta.

Priatinah dan Prabandaru (2012) "Pengaruh ROI, EPS, dan DPS terhadap harga saham perusahaan pertambangan yang terdaftar di BEI periode 2008-2010".

Pramita Riza Oktaviani (Jurnal Ilmu dan Riset Manajemen Volume 6, Nomor 2, Februari 2017), "Pengaruh PER, EPS, DPS, DPR Terhadap Harga Saham Perusahaan Pertambangan".

Sofyan Syafri Harahap. 2007. "Analisis Kritisatas Laporan Keuangan". Jakarta: PT Raja Grafindo Persada. 


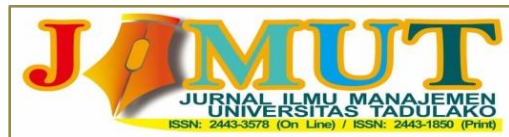

Vol. 7, No 3, Juli 2021, 289-299

Suad Husnan, (2001), "Dasar - Dasar Teori Portofolio dan Analisis Sekuritas". Edisi ketiga, UUP AMP YKPN, Yogyakarta.

Sugiono. 2014. Metode Penelitian Pendidikan Pendekatan Kuantitatif, Kualitatif Dan $R \& D$. Bandung: Alfabeta.

Sugiyono. (2013). Metode Penelitian Kuantitatif, Kualitatif dan R\&D. Bandung: Alfabeta.CV

Sugiyono. 2007. Metode Penelitian Bisnis. Alfabeta, Bandung.

Syamsuddin, Lukman, (2011): Manajemen Keuangan Perusahaan. Jakarta: Rajawali Pers.

Tandelilin, Eduardus. 2010. "Portofolio dan Investasi : Teori dan Aplikasi". Edisi Pertama. Yogyakarta : Kanisius.

Zaki, Baridwan. 2005. Sistem Akuntansi Penyusunan Prosedur dan Metode. Yogyakarta: BPEE Http://wikipedia.org/wiki/Pertambangan 